\title{
The Afterlives of Frantz Fanon and the Reconstruction of Postcolonial Studies
}

Bhakti Shringarpure

Journal of French and Francophone Philosophy - Revue de la philosophie française et de langue française, Vol XXIII, No 1 (2015) pp 113-128.

\author{
Vol XXIII, No 1 (2015) \\ ISSN 1936-6280 (print) \\ ISSN 2155-1162 (online) \\ DOI 10.5195/jffp.2015.676 \\ www.jffp.org
}

\section{(oc) BY-NG-ND}

This work is licensed under a Creative Commons Attribution-Noncommercial-No Derivative Works 3.0 United States License.

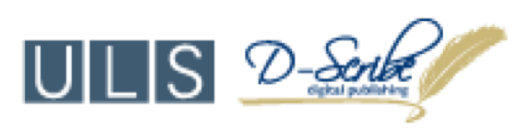

This journal is operated by the University Library System of the University of Pittsburgh as part of its D-Scribe Digital Publishing Program, and is co-sponsored by the University of Pittsburgh Press 


\title{
Review Essay
}

\section{The Afterlives of Frantz Fanon and the Reconstruction of Postcolonial Studies: A Review of Anthony C. Alessandrini, Frantz Fanon and the Future of Cultural Politics (Lanham: Lexington Books, 2014), 295pp.}

\author{
Bhakti Shringarpure \\ University of Connecticut
}

It is no easy task to add to the existing and somewhat saturated body of work on Frantz Fanon, which has found a renewed impetus in light of the events of the Arab Spring. The year 2011 not only marked fifty years since the death of Fanon at the young age of 36, but it is also fifty years since the publication of his heavily read and most impactful work, The Wretched of the Earth. Now, more than half a century after his death, the specter of Frantz Fanon haunts the field of postcolonial studies, and his reflections on decolonization, nationalism and violence seem more poignant than ever. Part of the reason is that, instead of a successful transition into nation-states, several of the ex-colonies have become sites for terrible conflicts in the name of ethnicity, race, power, religion and territory. Thus, the current context offers an opportunity to re-read Fanon's disturbing prophecy embedded in The Wretched of the Earth regarding the way in which the dream of decolonization would remain deferred in the years that followed, and to scrutinize more deeply his reflections on revolutionary violence.

In the last decade, there has been a significant rejuvenation in attempts to interpret Fanon for the new century. Anthony C. Alessandrini's Frantz Fanon and the Future of Cultural Politics: Finding Something Different (2014) is a masterful intervention into the theorizing and contextualizing of the way in which Fanon's work has been disseminated, appropriated and misappropriated by the Anglophone academy since English translations of his work started appearing posthumously in the late sixties. Earlier, in 2009, Immanuel Wallerstein published "Reading Fanon in the 21st Century" in New Left Review, but the essay does not necessarily fulfill the promise of its title. Evoking his few meetings with Fanon, and thus somewhat personal in 
style, Wallerstein re-evaluates some of the paradoxes in Fanon's theories on nationalism and violence and tries to bring attention to Fanon's views on class struggle. Achille Mbembe also enters the space being carved out for new readings and engagements with his "Metamorphic Thought: The Works of Frantz Fanon," which is an introduction to Fanon's complete works published in France. Mbembe claims: "Even if France is yet to fully experience the Fanon phenomenon, everything would seem to indicate that Fanon has finally emerged from the obscurity to which he has been relegated." Mbembe offers another iteration ${ }^{2}$ of his interpretation of Fanon's thinking about violence in light of the fact that "new forms of colonial warfare and occupation are taking shape, with their share of counterinsurgent tactics and torture, Guantanamo-style camps, secret prisons, their mixture of militarism and plundering of resources from afar." ${ }^{3}$

The year 2011 also marked the beginning of mass protests across several parts of the Arab world, where issues of revolution, violence, non-violence, solidarity, colonialism and neo-colonialism were suddenly brought to the forefront in mainstream as well as academic discourses. For Alessandrini, it is an occasion to connect the Arab Spring to Fanon by a simple geographic intervention. Since the key spaces of demonstrations, such as Tunisia, Egypt, Morocco, Algeria and Libya, are located in the African continent, we are compelled to examine the movements in light of Fanon's vision "of uniting Africa across the divisions that were themselves the concrete effects of the European 'scramble for Africa."' 4 Alessandrini's formulations about an "African Spring" offer an extended reading of Fanon's work on Africa itself. By situating the Arab spring within the African continent, he brings Fanon's writing to bear more directly upon the events, thus bringing a kind of urgency to the act of re-reading his work. A year before his death, Fanon had been seeking outside help for the Algerian Revolution and had begun shaping the "African Legion" project. Creating diplomatic ties with several African countries for this project took him to many places on the continent, such as Mali, Cameroon, Ghana, Guinea, Libya, Ethiopia and Congo. His attendance at the Pan-African conference in Accra and two Présence Africaine gatherings had put him in touch with some of the most important leaders and intellectuals from the African continent. ${ }^{5}$

While the relevance of Fanon today is certainly not up for debate, I would like to mobilize Fanon as a point of entry into mapping the current state of postcolonial studies, and within that, reflect on what constitutes the postcolonial canon. Over a gradual course of the eighties and nineties, there has come about a transition from the field's founding moments in which anti-imperialism, tricontinentalism, Third World nationalism and aesthetics of realism and resistance thrived, to the current trends that show a slant toward postmodernist fragmentation, multiculturalism, issues of diaspora, metropolitan narratives as well as a proclivity toward theorizing the field itself. There are many reasons for this: the specific dynamics of the post-Cold 
War American culture within which these works were received; the compromised relationship between academic and commercial publishing culture, which made a jump from atavistic narratives of decolonization and neocolonialism to metropolitan multiculturalism; and the sway of postmodernism over academia as a whole, which led to a disregard for Marxist theories and, more importantly, to a neglect of realism as a mode and aesthetic in postcolonial theory. These factors have worked together to shape how the genealogy of postcolonial studies and its theory have come to be accepted as "obvious." This has, in turn, had strong repercussions for the kind of literature and theory that have come to be celebrated and canonized within the field.

During the Cold War, covert actions and proxy wars funded and manipulated by the US and the USSR destabilized decolonization movements in most countries, but it was also the realm of culture, especially is the US, that was profoundly altered. Frances Stonor Saunders writes extensively about the CIA infiltration of cultural, artistic and university spaces in The Cultural Cold War, whereby, "[d]rawing on an extensive, highly influential network of intelligence personnel, political strategists, the corporate establishment, and the old school ties of the Ivy League universities, the incipient CIA started, from 1947, to build a 'consortium' whose double task it was to inoculate the world against the contagion of Communism, and to ease the passage of American foreign policy abroad." ${ }^{\circ}$ Culture became an active and potent agent in constructing narratives that boosted and legitimized foreign as well as national policies. As myriad projects unfolded in mainstream culture, universities and institutions, they led to a profound alteration in the kind of literature that began to be disseminated and celebrated. Andrew Rubin investigates the precise effects of this propaganda on literary culture as well as in academia in Archives of Authority: Empire, Culture and the Cold War (2013), and finds that "an entire reconfiguration of cultural relationships took place that has vast consequences for the position of the writer in society, the conditions of humanistic practice, the ideology of world literature, and finally, the relationship between writers and the rising dominance of new and efficient modes of mass transmission." P Postcolonial studies came into being as a field in the seventies and became, inadvertently, a space that was directly influenced by these political and cultural dynamics.

For example, the subject of decolonization was erased from the American university space as neocolonial, and meddlesome foreign policy ventures clamped down on any form of knowledge that was perceived as politically dangerous to the interests of the US. In particular, the field of African Studies was a highly manipulated space. In his article, "Students, Scholars and Spies: The CIA on Campus," Robert Witanek reveals the way in which campus recruitment, generous endowments, on-campus spy scholars and other ingenious tactics, the CIA embedded itself into the

Journal of French and Francophone Philosophy | Revue de la philosophie française et de langue française Vol XXIII, No 1 (2015) | http://www.jffp.org | DOI 10.5195/jffp.2015.676 
American academy. And so it traveled from campus to the newly decolonized regions and back again, as the sordid history of hundreds of CIA activities on campuses reveals. In one instance, the CIA had a strong interest in "inspiring African affairs programs" and, in fact, "[i]n 1956, when former CIA official Max Millikan was director of MIT's Center for International Studies, he appointed Arnold Rivkin from the State Department to head MIT's (Massachusetts Institute of Technology) Africa Research Program. Together, the two supervised studies for CIA use."i According to their research, they estimated the consistent need for about seventy people that specialized in areas of African economics, geography or political science, and used the University as a training ground and as a source of steady supply of so-called "specialists." Yet another example documents a manufactured vote in 1968 Guyana. "In 1968, the CIA used the Eagleton Institute for Research at Rutgers University in a plan to influence the outcome of the presidential election in Guyana. Through the Eagleton Institute, the CIA helped amend the Guyanese constitution to allow Guyanese and relatives of Guyanese living abroad to vote by absentee ballot. Then 16,000 votes were manufactured in New York City, giving the CIA's candidate, Forbes Burnham, a narrow margin over socialist Cheddi Jagan." ${ }^{\prime}$ No decolonizing region at the time was exempt from Cold War interests and connivance. The effects of these large-scale projects grounded in universities and publishing institutions continue to impact most academic fields to this day.

While Neil Lazarus explores the problems besetting the field of postcolonial studies at great length in The Postcolonial Unconscious (2011), it is not the first time ${ }^{10}$ Lazarus has explored the term itself and questioned its meaning and origin. In a 2004 essay, he wrote: "Before the late 1970s, there was no field of academic specialization that went by the name 'postcolonial studies.' Today, by contrast, postcolonial studies occupies a position of legitimacy and even relative prestige, not only within the Euro-American academy but also in universities in many countries of the formerly colonized world." " There are many advertisements for academic positions in the field, an outpouring of journals and anthologies, conferences and colloquia, as well university centers entirely devoted to postcolonial studies. Lazarus attributes the origins of the term to political scientists who were "using the term in a strict historically and politically delimited sense, to identify the period immediately following decolonization, when the various leaderships, parties, and governments which had gained access to the colonial state apparatuses at independence undertook to transform these apparatuses...Post-colonial (or 'postcolonial' - the American variant), in 
these usages from the early 1970s, was a periodizing term, a historical and not an ideological concept." ${ }_{12}$

However, the historical and chronological basis for this term could not be sustained and was transformed into something completely different. The term "postcolonial" went from being a particular periodizing term that defined the politics of the era following decolonization to a field within which almost any discussion on marginality, nationalism or immigration has come to be contained. ${ }^{13}$ Whether postcolonial theory is applied anachronistically for an understanding of Chaucer in the Middle Ages" ${ }^{4}$ or has begun to incorporate historically and spatially diverse regions from Australia to Asia, the US and Latin Americas, it has lost its position as a distinct category and critical tool to understand and analyze the long duration of European colonialism and its active repercussions today. Since its inception in the sixties and seventies, the field has taken on many different avatars, and publications and events in the nineties were a real turning point for the field.

It is not far-fetched to claim that postcolonial theory favors a certain kind of literature, and there is a strong preoccupation with formal elements. The following long quotation from Benita Parry expresses the field's neglect of any literature that is devoid of extravagant innovation or a postmodern sensibility. Parry writes:

Whereas the postcolonial novel covers heterogeneous narrative styles from the former British, French, Portuguese, and Dutch empires in Africa, Asia and the Americas, critics display an excessive interest in the fiction of migrants, and within this subgenre, in extravagant innovation. Hence partisan and resistance literature, as if considered devoid of aesthetic qualities, remains a minority interest (Harlow 1987, San Juan 1988), "realist" diasporic writing is marginalized, while popular fictions from the postindependence nation-states written in local languages and deemed uncongenial to metropolitan taste are untranslated and largely undiscussed within the academies...These variations suggest that, instead of attempting to compile a canon of Postcolonial Literature, we need to think about postcolonial literatures as a web of different strands, not all of which are woven out of "postmodern" materials.

Here, Parry is taking issue with postcolonial theory's tendency to legitimize terms such as "hybridity" as a lens for the aftermaths of colonialism, and that has been seen as part of the problem of its trajectory. Hybridity becomes a critical tool for understanding the effects of slavery on populations in the Americas and the Caribbean, and the creolization of cultures without subscribing to essentialist theories. It becomes specifically linked with postcolonial theory with the publication Homi Bhabha's book The Location of Culture, and hereby aligns itself with the onset of large-scale migration and

Journal of French and Francophone Philosophy | Revue de la philosophie française et de langue française Vol XXIII, No 1 (2015) | http://www.jffp.org | DOI 10.5195/jffp.2015.676 
its effects on a collective multicultural awareness and identity. This category presumes a particularly metropolitan inclination and especially focuses on the migrant intellectual in an urban space.

As fluidity and travel between spaces and ideas shrinks, hybridity becomes a kind of privileged condition, and according to Aijaz Ahmed, unfortunately evokes "the postcolonial who has access to such monumental and global pleasures is remarkably free of gender, class, identifiable political location." ${ }_{16}$ The gap between postcolonial reality and theory widens as previously colonized places in Asia and Africa experience continued breakdown in communication and education systems, terrifying levels of poverty and acute hunger, as wells as wars and genocides which threaten the very possibility of human existence. Ahmed also takes issue with Bhabha's claim to "displacement" as a general human condition and as philosophical position. He reminds us that only the privileged can be voluntarily mobile and feel free to shape their identities, whereas " $[\mathrm{m}]$ ost migrants tend to be poor and experience displacement not as cultural plenitude but as torment; what they seek is not displacement but, precisely, a place from where they may begin anew, with some sense of the stable future. Postcoloniality is also, like most things, a matter of class." ${ }_{17}$

Using somewhat different methodologies, both Neil Lazarus and Anthony C. Alessandrini offer correctives on the existing genealogy of postcolonial studies. Lazarus and Alessandrini's books were published three years apart, but they exist in a continuum. Lazarus' thesis that imperial violence in sites such as Iraq and Afghanistan should be located within postcolonial studies finds impetus in Alessandrini's analysis of the Arab Spring. In arriving at situating postcolonial studies within current contexts of globalized imperialisms and neo-colonialisms, both are compelled to address Fanon. Juxtaposing the two works yields a strong intervention into the ways in which the genealogy of the field of postcolonial studies has taken erroneous turns, and within these, the ways in which Fanon studies has been appropriated in the service of those agendas. Furthermore, the two books offer clear ways to re-integrate more openly revolutionary and Thirdworldist theories back into the field.

Lazarus claims that, while there was some discussion about figures from the decolonization era (Senghor, Castro, Guevara, Gandhi, etc.) in postcolonial studies, Fanon was the only thinker whose work was considered "essential" in the eighties and nineties by intellectuals who were urging rigorous engagement with his work. Lazarus admits to having foreseen an implosion under which the contradictory, selective and often disjointed critical work on Fanon would collapse had it not been rescued and rehabilitated by the "magisterial" biography Frantz Fanon by David Macey published in 2000. "Macey's study is one of those rare works that breaks open the field into which it intervenes, enforcing in the process a reconfiguration not only of its boundaries but also of its internal

Journal of French and Francophone Philosophy | Revue de la philosophie française et de langue française

Vol XXIII, No 1 (2015) | http://www.jffp.org | DOI 10.5195/jffp.2015.676 
arrangements and relations." ${ }^{18}$ Lazarus finds Macey's construction of the "meaning" of Fanon into two "conflicting and incompatible schemas" particularly useful. The first one contains the liberationist Third Worldism that addresses the revolutionary anticolonial nationalism in the post-1945 period. The second schema contradicts the first by addressing the "rolling back of insurgent anticolonial nationalism by the imperialist powers since 1975 or so, and also, accordingly, from the assumed obsolescence of the earlier liberationist Third-Worldist ideologeme." ${ }_{19}$ Lazarus situates the origins of post-colonial studies within the second moment, which is the coming of globalization and neo-imperialism. Within this context, the ThirdWorldist Fanon had waned and did not fit the agenda of the field, thus leading to the creation of what Macey called a "postcolonial Fanon." This is a less angry Fanon, and the focus is not as much on The Wretched of the Earth or revolutionary ideas, but, according to Macey, to "construct a Fanon who exists outside time and space and in a purely textual dimension." ${ }^{20}$ Here, Homi Bhabha is the main scholar being implicated for having brought this particular Fanon into existence.21 While Lazarus does not believe this postcolonial Fanon is completely subverted by Macey's work, he does find that Macey succeeds in establishing both schemas as being related to one another. Both schemas "appropriate Fanon for their own historically specific projects; both construct him in the image of their own ideological concerns." ${ }_{22}$ In fact, Macey's goal, according to Lazarus, is to focus on Fanon as a singular figure, and part of this project includes a resurrection of the distinctly Fanonian "characterological features" such as anger, even rage, impulsiveness, passion, overarching intensity regarding ethics, impatience and a sense of urgency around political issues.

In light of the neocolonial excursions in the Middle East, terrorist attacks in various Western cities, the War on Terror and the relentless cycle of violence that the world is currently in the grip of, Lazarus has seen the limitations of the field:

Yet if scholars in postcolonial studies have clearly been critical of the 'war on terror' and reassuringly unimpressed by the sophistries purveyed by the retinue of state ideologists and policy hacks attempting to justify it, they have not typically seen the contemporary developments as requiring them to do any rethinking themselves about the assumptions and common understandings prevailing in their own field. On the contrary, there has been a tendency to insist that what is urgently needed in the context of the debacles in Iraq and Afghanistan is more of precisely the kind of theory that has already been prevalent in the 1980s and 1990s. ${ }^{23}$

Over the course of the past decade, Lazarus has consistently argued for a redirecting of concerns and methodologies within postcolonial studies. In the above quotation, he refers to Sangeeta Ray's call for continued

Journal of French and Francophone Philosophy | Revue de la philosophie française et de langue française Vol XXIII, No 1 (2015) | http://www.jffp.org | DOI 10.5195/jffp.2015.676 
engagement with "specular, border intellectuals" through the politics of alterity as an example of irony within the field, which predicated this idiom of alterity on the premise that imperialism is obsolete. It also serves as an example to maintain his assertion that postcolonial studies has mobilized a set of theories, concepts, methods and assumptions that have fundamentally failed to address its object of study which is the postcolonial world and have systematically served to "mystify" it. Yet, in The Postcolonial Unconscious, Lazarus wants to move past criticism and contention and urgently begin the work of what he calls "reconstruction." Here, his book does very important work of re-reading canonical thinkers who have shaped the field, such as Edward Said, Frantz Fanon, Homi Bhabha and Frederic Jameson, as well as rethinking the tropes, themes and theories that have come to define the field. Thus, when it comes to Fanon, "[a]ny argument in favor of the postcolonial Fanon must rest on the hypothesis of a radical break between the world order of Fanon's own time - the period of 'Third World' insurgency - and that of today." It is precisely this dichotomy that Lazarus wants to reject, and he hopes to appropriate Fanon with the potency and resurrective qualities that his anger may represent to formulate a global anti-imperialist and anti-capitalist critique against the violent events inspired by the "new world order" in Iraq and Afghanistan. Lazarus concludes that "his work seems, to me, to have lost nothing of its relevance or its urgency." ${ }_{24}$

While Lazarus' book, with its one chapter on Fanon, speaks to the significance of Fanon in postcolonial studies, it is Alessandrini's comprehensive book focused only on Fanon that proves how the thinker and the field are inextricably bound together. In this book, we can find multiple points of entry into the debate on the genealogy of postcolonial studies and the politics of postcolonial canon formation. Firstly, the discussion around problematic appropriations of Fanon strikes me as being symbolic as well as analogous to the problematic appropriations of postcolonial studies. The uses and misuses of Fanon in his after-life become a microcosm within which the larger life of postcolonial studies can be observed. In Alessandrini's anxiety with Deborah Levy's anachronistic need to "apply" Fanonian thinking to racism in postcolonial London, I find a mirror to the ways in which postcolonial studies is similarly evoked in situations that may have scant historical and political links..$^{25}$ While Levy is concerned with firmly placing Fanon within contemporaneity, Alessandrini's approach differs with regards to the belief that "the most productive way to revisit Fanon today, and to engage with him as a contemporary, is not to simply wrest him from the past into the present, but precisely to deal with his life and work in all its singularity." ${ }_{26}$ Singularity becomes a theoretical tool, and in differentiating singularity from specificity, Alessandrini writes that he has been motivated by "a desire to play both scrupulous attention to the specificity of particular political and historical contexts, and a scrupulous remembrance that engaging in politics necessarily involves struggling towards the sorts of difficult generalizations

Journal of French and Francophone Philosophy | Revue de la philosophie française et de langue française

Vol XXIII, No 1 (2015) | http://www.jffp.org | DOI 10.5195/jffp.2015.676 
that make collective social change possible." Lazarus' and Alessandrini's preoccupation with making Fanon's work relevant to social change, activism and solidarity is evident here, and they both believe that it is through these paradigms that reconstruction can begin not only with regards to the afterlife of Fanon, but also in the field of postcolonial studies of which Fanon is a founding force.

One of Alessandrini's most dynamic contributions to the field of Fanon studies is his methodology, which consists of revisiting Fanon's work through pairings with other influential and canonical writers, namely Edward Said, Michel Foucault, Jamaica Kincaid and Paul Gilroy. Alessandrini explicitly addresses his investigation of postcolonial studies in the title of his chapter on Said and Fanon, "Towards a New Genealogy of Postcolonial Studies." Here, he makes a familiar claim attributing Marxist and Marxist-influenced analyses undertaken by anti-colonial and decolonization intellectuals to the origins of the field, as opposed to viewing the field as having been birthed by postmodernism. He engages Edward Said's influential essay, "Traveling Theory," which asks: "What happens to [the theory or idea] when, in different circumstances and for a new reasons, it is used again and, in still more different circumstances, again?" In order to create an alternate trajectory for writings on humanism, Alessandrini now pairs Said and Fanon and finds "Traveling Theory" to be a useful framework for working through "the form a theory takes at its moment of arrival rather than its point of origin." ${ }_{27}$ Leaving the question of humanism aside for the moment, what is more striking about this essay is the way in which Alessandrini reconfigures Said's legacy within postcolonial studies. The influence of Foucault upon Said's work, particularly in Orientalism, is often acknowledged above others. One could even argue that it is Said's Orientalism that places Foucault's oeuvre firmly within postcolonial studies and actually makes the structuralist, post-structuralist and postmodern French theorists pivotal to the field. What is often left out of the exegeses of Said's writings is his debt to Fanon. Algeria is to Fanon what Palestine is to Said, Alessandrini seems to be positing. It is the theoretical, ideological and philosophical journeys to articulate those counter-cultural politics and identities that binds the two. It is at this juncture that Alessandrini's intervention and analyses are particularly powerful. ${ }^{28}$

Alessandrini reinforces the connection between Said and Fanon by making two points. The first is that Said's engagement with Foucault often yields theoretical inconsistencies, and these can be attributed to "particular conjunctures in the Palestinian struggle," or "symptoms of particular historical pressures." ${ }_{29}$ In the reception of Said's oeuvre, his literarytheoretical work and political work have often been perceived as two separate bodies. Fanon, here, becomes a crucial conduit that fuses the two inseparable aspects of Said's work and dismantles artificial divisions. Alessandrini's second point addresses this problem by delving into Said's

Journal of French and Francophone Philosophy | Revue de la philosophie française et de langue française Vol XXIII, No 1 (2015) | http://www.jffp.org | DOI 10.5195/jffp.2015.676 
efforts to bridge the political and professional. Here, Alessandrini revisits the famous schism between Said and Palestine Liberation Organization (PLO) leader Yasser Arafat over the Oslo Accords. Said had continued to insist that it was Arafat's inadequate linguistic, analytical and close-reading abilities that made him accept the limited autonomy being given to the Palestinian people as opposed to real liberation. Alessandrini believes that Fanon "was also concerned with misreadings, especially those performed by what he called "native intellectuals," and finds that The Wretched of the Earth abounds with examples of such misreadings in which his criticism of the ways in which colonial powers exploit the shortcomings of decolonization leaders are unabashed.

Finally, it is their engagement with humanism that unites the two thinkers. Both Said and Fanon attempted to articulate what appeared to be a theoretically inconsistent humanism due to its clash with seemingly antihumanist articulations. Anticolonial thinking has been forced to contend with and strategize against Europe's humanist hypocrisies originating in the era of Enlightenment. Critics have argued that paradoxes within Said's more Foucauldian formulation were due to a "residual humanism." Alessandrini overturns such arguments by claiming that Said was instead practicing a decidedly Fanonian "emergent humanism." To illustrate this point, Alessandrini uses the example of Said's 1995 piece for Al-Hayat about George H.W Bush's attempts to place an unprecedented hegemony in the Middle East with the first Gulf War. Said wrote that the language of US foreign policy continues to regurgitate the same old ideas, the exertion of the same brute force, and has no fresh vision of the future. He concludes that, "the Great White Father...has come to the end of his reign. A new era is dawning." Alessandrini finds this moment particularly poignant and observes that, as with Fanon, this is aimed at the victims, who "must also become the victors, the inheritors of this new era that must be brought into existence. This is the language of emergence, not residue; it has always been at the heart of Said's work." ${ }^{\text {зо }}$ Alessandrini sums up the chapter thus:

The goal, as Fanon put it fifty years ago, is to create a critical consciousness "freed from colonialism and forewarned against any attempt at mystification or glorification." If we are to understand the work done (and yet to be done) by postcolonial theory - not just the work of Fanon and Said, but also work that has been inspired by their examples (including the work that you are reading now) as more than just a particularly successful offshoot of "postmodernism," we need to understand precisely what is at stake in their struggles within humanism, especially as it relates to the historical forces that condition, and continue to condition such struggles. This is especially important if we are to acknowledge that just as history, has not yet ended, neither have the legacy and practices of colonialism. ${ }^{31}$

Journal of French and Francophone Philosophy | Revue de la philosophie française et de langue française Vol XXIII, No 1 (2015) | http://www.jffp.org | DOI 10.5195/jffp.2015.676 
This particular convergence of Said and Fanon immediately places postcolonial studies in direct alignment with discourses on social change in a way Lazarus would surely view as the work of "reconstruction." The chapter that pairs Fanon with Antiguan writer Jamaica Kincaid, aptly titled "The Futures of Postcolonial Criticism," continues this agenda in an even more pointed manner. Alessandrini begins by pointing out that Fanon's most poignant contribution is not focused on the "postcolonial condition," but represents a fundamental and challenging paradox as it ponders "what might, through the anti-colonial struggle, be brought into existence after postcolonialism." ${ }_{32}$ The connection to postcolonial criticism is made swiftly by the claim that "the ambivalence that can be found throughout Fanon's work is also the central ambivalence in postcolonial criticism today." Alessandrini states that postcolonial studies suffers from a prematurely celebratory tone in which the "post" may subsume existing discourses on neo-colonialism as well as the tangible aftermaths of colonialism itself, even if it has issued a much-needed challenge to Eurocentric writing, has made room for new voices from formerly colonized regions and offered comparative frameworks to study disparate locations. In addition to Alessandrini's criticism, critics like Lazarus have also claimed that there has been a deliberate re-centering of the field characterized by its move away from Marxist theory toward postmodernism as well as the canonization and celebration of metropolitan, multiculturalist writing over Third Worldist literature.

In an unusual but perhaps unsurprising turn, scholars have looked at the American academy in the aftermath of the Vietnam War as a charged site to find the answers for the larger question of the postcolonial canon. Jim Neilson's Warring Fictions: American Literary Culture and the Vietnam War Narrative traces the trends within literary culture, mass media and the academy by analyzing the reception of Vietnam War literature, a phenomenon very much related to Cold War politics, as well. In so doing, Neilson reveals "not merely the vicissitudes of literary taste but the ideology of literary culture." ${ }_{33}$ While he does not address postcolonial studies, he creates a framework to expose the workings of a literary culture that shapes perceptions about colonialism, globalization and foreign wars, as well as the receptions of and perceptions about those non-western wars. Two of the most obvious outcomes in publishing at the time are, firstly, the advancement of a particular American literature and narrative that managed to push international and translated works to the margins, and secondly, an emergence of a bureaucratic network of agents, editors and reviewers who dominate and remain in charge of shaping the commercial literary scene. Neilson's research is focused on the seventies and eighties, and his work reveals the precise nexus at which the publishing world found itself in the aftermath of Cold War ideologies and the sweeping corporatization of the industry itself. Often unintended, it has consistently led to a marginalization of views outside of a manufactured, consensual narrative.

Journal of French and Francophone Philosophy | Revue de la philosophie française et de langue française Vol XXIII, No 1 (2015) | http://www.jffp.org | DOI 10.5195/jffp.2015.676 
Neilson asks "how, against the best efforts of so many, did a war once perceived as a nearly genocidal slaughter to perpetuate American neocolonialism come to be viewed as an American tragedy?" ${ }^{34}$ One could ask a similar question about postcolonial studies, extending the consideration of how postcolonial studies re-inflected Fanon's work. How did the study of an inhumane history of colonialism with its multiple genocides, massacres, tortures and extreme exploitation come to be viewed through the lens of identity crises, cosmopolitanism or hybridity? Neilson's attempts to understand the way in which academic and commercial culture completely transform and reverse an historical event can be applied to my dilemma regarding postcolonial studies. Why is it that Vietnam ends up on the margins of American literature departments, ignored by academic associations and publishers, whereas postcolonial studies begins to thrive? Part of the reason is that this particular moment in time in the United States also sees the rise of a particularly distinct multicultural curriculum. As more African-American and immigrant students were integrated into the school and university system, tensions regarding language of instruction, and issues of cultural assimilation and pluralism came about. It became mandatory to assign literatures from different cultures, regions and languages, and it is no surprise that more "diverse" writing also became a mainstream staple in bookstores, book clubs and within a broader realm of culture. ${ }^{35}$ The same moment also heralded what came to be called the "culture wars" or the "canon wars." It also illustrates through yet another lens that it was a very specific set of conditions that enabled the move away from adopting foreign, rural narratives to taking up more multiculturalist, immigrant ones set in metropolitan centers themselves. Possibly, the very reason that leads to the exclusion of a Vietnam War literature canon is also the reason that a certain kind of postcolonial literature and theory thrives.

In returning to the work of Jamaica Kincaid and its connections to Fanon, Alessandrini quotes the author of the 2008 novel Fanon, John Edgar Wideman, who yearns to be somebody like Fanon, whom he describes as "unflinchingly honest" and "scary." In evoking Fanon's intensity, Alessandrini touches upon the characterological aspects of the thinker that Lazarus wishes to resurrect, particularly the potent brand of Fanonian anger. The arrival of Jamaica Kincaid, with her firebrand style and lack of hesitation to offend readers and critics, onto the stage with Fanon could not be more fitting, particularly given both writers' penchant for direct address. ${ }^{36}$ In this chapter, Alessandrini situates Fanon as a Caribbean writer like Kincaid and proves that both share "an emphasis on what large historical forces have done to the inhabitants of small places in the Caribbean," and thus effectively address post-Cold War neo-imperialisms as well as globalization. Through a close reading of A Small Place along with Black Skin, White Masks, Alessandrini finds that "Kincaid's work thus provides a particularly dramatic illustration of Fanon's insight that colonialism is a purely destructive force for the colonized." ${ }^{37} \mathrm{He}$ also concludes that both

Journal of French and Francophone Philosophy | Revue de la philosophie française et de langue française

Vol XXIII, No 1 (2015) | http://www.jffp.org | DOI 10.5195/jffp.2015.676 
Fanon and Kincaid are engaged in creating new forms of "postcolonial subjectivity," particularly through "imaginative writing" that becomes "crucial for transforming our (not yet) postcolonial condition." 38 Alessandrini rightly infers that these books rupture the ambivalence afflicting the status of postcolonial criticism. They reinstate the history of colonialism into the field in a way that it is no longer only located in the past, but becomes part of a dynamic present.

Reading Kincaid alongside Fanon also positions women and gender studies interventions as key components in a field that has tended to replace the great white male intellectuals with great brown or black men. Critics like Gayatri Spivak, Chandra Talpade Mohanty and Vandani Shiva, or writers like Ama Ata Aidoo, Ismat Chugtai, Assia Djebar and Mariama Bâ, are not given the canonical status that people like Edward Said, Frantz Fanon, Salman Rushdie or Ngugi wa Thiong'o have been granted. Alessandrini offers a directive for filling this gap, since contemporary readings of Fanon (Lazarus, Wallerstein, Mbembe) do not acknowledge that the process of constructing and reconstructing the field of postcolonial studies is also a gendered one.

In heeding Lazarus' and Alessandrini's calls for the reconstruction of postcolonial studies at the level of representation of its genealogy and in terms of reconsidering themes that have fallen by the wayside as the field has evolved, both critics are asking for a close scrutiny of present-day political and ideological structures that are directly implicated in the unceasing, violent upheavals of our time. These range from the wars in Iraq and Afghanistan to the War on Terror and the Arab Springs. I would like to add that, while Lazarus' and Alessandrini's interventions offer impressive and impactful correctives on the field's blind spots, there is very little focus on internecine violence and civil wars that have been part of the postcolonial landscape. In the past sixty years, approximately 243 large and small conflicts $^{39}$ have been reported. These can be traced back to the decolonization period, which often saw colonial regimes being replaced by brutal dictatorships or can be attributed to the connivance of Cold War interference starting a cycle of proxy wars. Literary representation of this phenomenon is widespread, with hundreds of published novels, poetry, drama and nonfiction, though not necessarily through mainstream channels. The curious absence of this particular topic as a dominant and pivotal component in postcolonial studies remains unchallenged due to the fact that contemporary academic-literary culture nurtures and propagates an entirely different body of postcolonial writing. The focus has been on metropolitan narratives that privilege the experience of migration, and there has not been enough engagement with working through the past injustices of colonialism and their repercussions today. Crucial attention must to be paid to the writing emerging from these contexts and, given that violence and neo-imperialism 
are key signifiers in these texts, Fanon's oeuvre is inextricable from this study.

\title{
Bhakti Shringarpure
}

\author{
University of Connecticut
}

${ }^{1}$ Wallerstein, Immanuel. "Reading Fanon in the 21st Century.” New Left Review, Issue 57, May-June 2009, pp 117-125.

2 The first iteration of Achille Mbembe's thesis on Fanon's conceptions of violence appeared in his chapter "Out of this World" in On the Postcolony, (University of California Press, Berkeley, 2001), pp 173-211.

${ }^{3}$ Achille Mbembe (2012). “Metamorphic Thought: The Works of Frantz Fanon, African Studies, 71:1, 19-28.

${ }^{4}$ Alessandrini, Frantz Fanon and the Future of Cultural Politics, 168.

${ }^{5}$ Macey, David. Frantz Fanon a Biography. (New York: Picador USA, 2001).

${ }^{6}$ Saunders, Frances Stonor, The Cultural Cold War: The CIA and the World of Arts and Letters, (The New Press, 2013), 6.

${ }^{7}$ Rubin, Andrew, Archives of Authority: Empire, Culture and the Cold War (Princeton University Press, 2013), 31.

${ }^{8}$ Witanek, Robert, Students, "Scholars, and Spies: The CIA on Campus" Covert Action Information Bulletin, Winter 1989, pp. 25-28. http://www.namebase.org/campus/witanek.html

${ }^{9}$ Witanek, Robert, Students, "Scholars, and Spies: The CIA on Campus" Covert Action Information Bulletin, Winter 1989, pp. 25-28. http://www.namebase.org/campus/witanek.html

${ }^{10}$ See Jeffrey Jerome Cohen's Postcolonial Middle Ages (Palgrave-Macmillian, 2001).

${ }^{11}$ Lazarus, Neil, The Cambridge companion to postcolonial literary studies, (New York: Cambridge UP, 2004), 1.

${ }^{12}$ Lazarus, Neil, The Cambridge companion to postcolonial literary studies, 2.

${ }^{13}$ See McClintock, Anne, "The Angel of Progress: Pitfalls of the Term "Post-Colonialism" Social Text, No. 31/32, Third World and Post-Colonial Issues (1992), pp. 84-98 and Appiah, Kwame Anthony, "Is the Post- in Postmodernism the Post- in Postcolonial?" Critical Inquiry, Vol. 17, No. 2 (Winter, 1991), pp. 336-357.

${ }^{14}$ See Jeffrey Jerome Cohen's Postcolonial Middle Ages, Palgrave-Macmillian, 2001.

${ }^{15}$ Parry, Benita, “Directions and Dead-ends in Postcolonial Studies.” in Relocating Postcolonialism, ed. Goldberg, David Theo and Quayson, Ato (Oxford, UK; Malden, MA: Blackwell Publishers, 2002), 72.

Journal of French and Francophone Philosophy | Revue de la philosophie française et de langue française Vol XXIII, No 1 (2015) | http://www.jffp.org | DOI 10.5195/jffp.2015.676 
${ }^{16}$ Ahmad, Aijaz. In Theory: Classes, Nations, Literatures. (London; New York: Verso, 1992), 13.

${ }^{17}$ Ahmad, Aijaz. In Theory: Classes, Nations, Literatures. (London; New York: Verso, 1992), 16.

${ }^{18}$ Lazarus, Neil, The Postcolonial Unconscious (Cambridge, UK: Cambridge University Press, 2011), 162.

${ }^{19}$ Lazarus, Neil, The Postcolonial Unconscious, 165.

${ }^{20}$ Lazarus quotes Macey here: “'Third Wordlist’ readings largely ignored the Fanon of Peau Noire, masques blancs, post-colonial readings concentrate almost exclusively on that text and studiously avoid the question of violence. The Third Worldist Fanon was an apocalyptic creature; the post-colonial Fanon worries about identity politics, and often about his own sexual identity, but he is no longer angry." (28)

${ }^{21}$ Yet another iteration of this discussion can be found in Lazarus, Neil, "Disavowing decolonization: Fanon, nationalism, and the question of representation in postcolonial theory" in Frantz Fanon: Critical Perspectives, ed. Alessandrini, Anthony C. (Routledge, New York, 1999).

${ }^{22}$ Lazarus, Neil, The Postcolonial Unconscious, 167.

${ }^{23}$ Lazarus, Neil, The Postcolonial Unconscious, 16.

${ }^{24}$ Lazarus, Neil, The Postcolonial Unconscious, 182.

${ }^{25}$ Alessandrini's discussion on Deborah Levy's 2000 essay can be found in Alessandrini, Frantz Fanon and the Future of Cultural Politics, 3-8.

${ }^{26}$ Alessandrini, Frantz Fanon and the Future of Cultural Politics, 6.

${ }^{27}$ Frantz Fanon and the Future of Cultural Politics, 50.

${ }^{28}$ Alessandrini, Frantz Fanon and the Future of Cultural Politics, 50-51.

${ }^{29}$ Alessandrini, Frantz Fanon and the Future of Cultural Politics, 69-70.

${ }^{30}$ Alessandrini, Frantz Fanon and the Future of Cultural Politics, 70-71.

${ }^{31}$ Alessandrini, Frantz Fanon and the Future of Cultural Politics, 73.

${ }^{32}$ Alessandrini, Frantz Fanon and the Future of Cultural Politics, 101.

${ }^{33}$ Neilson, Jim, Warring Fictions : American Literary Culture and the Vietnam War Narrative, (Jackson: University Press of Mississippi, 1998) 6.

${ }^{34}$ Neilson, Jim, Warring Fictions: American Literary Culture and the Vietnam War Narrative, Jackson: University Press of Mississippi, 1998, 6.

${ }^{35}$ See Celik, Rasit, "A History of Multicultural Education in the USA: Origins, Approaches and Misconceptions," The Online Journal of New Horizons in Education, Vol 2, Issue 4, Oct 2012 and Bloom, Allan The Closing of the American Mind: How Higher Education Has Failed Democracy and Impoverished the Souls of Today's Students. Simon and Schuster, 1987.

${ }^{36}$ See Frederick, Rhonda D. "What If You're an "Incredibly Unattractive, Fat, Pastrylike-Fleshed Man?: Teaching Jamaica Kincaid's "A Small Place"'" College Literature, Vol. 30, No. 3 (Summer, 2003), pp. 1-18; King, Jane, "A Small Place Writes Back," Callaloo, Vol. 25, No. 3 (Summer, 2002), pp. 885-909 and Gauche, Suzanne, "A Small Place: Some Perspectives on the Ordinary," Callaloo, Vol. 25, No. 3 (Summer, 2002), pp. 910-919 
128 | Review Essay

${ }^{37}$ Alessandrini, Frantz Fanon and the Future of Cultural Politics, 117.

${ }^{38}$ Alessandrini, Frantz Fanon and the Future of Cultural Politics, 133.

${ }^{39}$ Taken from The New COW War Data, 1816 - 2007 (v4.0) -

http://www.correlatesofwar.org/COW2\%20Data/WarData_NEW/WarList_NEW.html

and more specifically, Intra-state War data set .

Journal of French and Francophone Philosophy | Revue de la philosophie française et de langue française Vol XXIII, No 1 (2015) | http://www.jffp.org | DOI 10.5195/jffp.2015.676 